\author{
Łukasz Dudzińskia)*, Dominik Wysocki ${ }^{\text {b) }}$, Łukasz Czyżewskic) \\ a) Municipal Headquarters of the State Fire Service in Lublin / Komenda Miejska PSP Lublin \\ b) Provincial Headquarters of the State Fire Service in Lublin / Komenda Wojewódzka PSP Lublin \\ c) Medical University of Warsaw, Department of Nephrology Nursing / Warszawski Uniwersytet Medyczny,

\title{
Health Hazards in Combat Division in the State Fire Service as Assessed by Officers of the Lubelskie Voivodeship
}

\section{Zagrożenia zdrowotne w podziale bojowym w Państwowej Straży Pożarnej w ocenie funkcjonariuszy województwa lubelskiego}

\begin{abstract}
Purpose: The aim of the study is to analyse health threats and occupational risk based on the assessment of the State Fire Service (SFS) officers depending on the nature of the service performed in the combat division (commander, rescuer, driver).

Material and methods: The questionnaire survey which was carried out included 181 officers serving in SFS units across the Lubelskie Voivodeship. An original questionnaire consisting of 16 questions was used as a research tool. The opening questions concerned the age and service experience of the respondents. The remaining questions with a 5-point Likert scale, a point-rating scale and single-choice questions (YES/NO) referred to how the officers assess health threats in their service and the risk level for individual professional duties.

Results: $50.8 \%$ of the respondents served as SFS rescuers, $32.1 \%$ as commanders, and $17.1 \%$ as drivers. One incident of damage to the skeletal system in the year before the survey was reported by 30 (16.6\%) firefighters (including 19 rescuers). 26 (14.4\%) firefighters (12 commanders) declared from 2 to 4 injuries. None of the firefighters declared more than 15 skeletal injuries per year. It was shown that firefighting activities were associated with the highest risk of health hazards - they concerned $20(11.1 \%)$ firefighters. Sports activities were characterised by a high risk of injury, which was confirmed by 14 (7.7\%) firefighters in the survey. 31 (17.1\%) firefighters (14 rescuers, 12 commanders and 5 drivers) experienced stress reactions $2-4$ times a year, while 6 (3.3\%) officers (3 rescuers, 3 drivers) declared them to happen more than 15 times a year.

Conclusions: The analysis showed that health risks of firefighters occupying various positions in the combat division is at a similar level. Numerous health risks in the form of bodily injuries occur as a consequence of sports activities. At the same time participation in operational readiness inspections and training classes is considered as posing the least risk. The use of personal protective equipment and proper protection of the rescuers' respiratory system have an impact on reducing the health risk during the service.

Keywords: accident at work, rescue and firefighting activities, State Fire Service, health hazards Type of article: original scientific article
\end{abstract}

Received: 13.07.2020; Reviewed: 06.08.2020; Accepted: 02.09.2020;

Authors' ORCID IDs: Ł. Dudziński - 0000-0002-8255-7608; D. Wysocki - 0000-0001-6144-0198; Ł. Czyżewski - 0000-0001-9473-9954;

Percentage contribution: Ł. Dudziński - 70\%; D. Wysocki-20\%; Ł. Czyżewski - 10\%;

Please cite as: SFT Vol. 56 Issue 2, 2020, pp. 110-125, https://doi.org/10.12845/sft.56.2.2020.7;

This is an open access article under the CC BY-SA 4.0 license (https://creativecommons.org/licenses/by-sa/4.0/).

\section{ABSTRAKT}

Cel: Celem pracy jest analiza zagrożeń zdrowotnych oraz ryzyka zawodowego w ocenie funkcjonariuszy Państwowej Straży Pożarnej w zależności od charakteru pełnionej służby w podziale bojowym (dowódca, ratownik, kierowca).

Materiał i metody: Przeprowadzono badanie ankietowe, którym objęto 181 funkcjonariuszy pełniących służbę w jednostkach PSP województwa lubelskiego. Narzędziem badawczym był autorski kwestionariusz ankiety składający się z 16 pytań. Metryczka dotyczyła wieku i stażu służby ankietowanych. Pozostałe pytania z pięciostopniową skalą Likerta, punktową skalą oceny oraz pytania jednokrotnego wyboru (TAK/NIE) dotyczyły tego, jak funkcjonariusze oceniają zagrożenia zdrowotne w służbie oraz poziom ryzyka dla poszczególnych obowiązków służbowych.

Wyniki: 50,8\% wszystkich respondentów stanowili ratownicy PSP, 32,1\% - dowódcy, natomiast 17,1\% - kierowcy. Jednokrotne uszkodzenia w układzie kostno-szkieletowym w ciągu roku poprzedzającego badanie zgłosiło 30 strażaków, czyli 16,6\% respondentów (w tym 19 ratowników). Od 2 do 4 urazów zadeklarowało 26 strażaków, tj. 14,4\% respondentów (w tym 12 dowódców). Powyżej 15 uszkodzeń w układzie kostno-szkieletowym rocznie nie deklarował żaden funkcjonariusz. Wykazano, że działania gaśnicze były obciążone największym ryzykiem wystąpienia zagrożeń zdrowotnych - dotyczyły 
20 strażaków (11,1\% ankietowanych). Zajęcia sportowe cechowały się dużym ryzykiem kontuzji, co potwierdziło w ankiecie 14 strażaków (7,7\% badanych). Reakcje na stres pojawiły się u 31 strażaków (17,1\% ankietowanych, w tym 14 ratowników, 12 dowódców i 5 kierowców) z częstotliwością od 2 do 4 razy w roku, natomiast ich wystąpienie powyżej 15 razy w ciągu roku deklarowało 6 funkcjonariuszy (3,3\% ankietowanych, w tym 3 ratowników i 3 kierowców). Wnioski: Jak wykazała analiza, zagrożenie zdrowotne strażaków zajmujących różne stanowiska w podziale bojowym kształtuje się na podobnym poziomie. Liczne zagrożenia dla zdrowia w postaci obrażeń ciała występują podczas zajęć sportowych, natomiast jako najmniej ryzykowne aktywności uznano udział w inspekcjach gotowości operacyjnej i zajęcia szkoleniowe. Na zmniejszenie ryzyka zagrożenia zdrowotnego podczas służby ma wpływ stosowanie środków ochrony indywidualnej oraz właściwe zabezpieczenie ratowników w zakresie ochrony dróg oddechowych.

Słowa kluczowe: wypadek w pracy, działania ratowniczo-gaśnicze, Państwowa Straż Pożarna, zagrożenie zdrowotne

Typ artykułu: oryginalny artykuł naukowy

Przyjęty: 13.07.2020; Zrecenzowany: 06.08.2020; Zaakceptowany: 02.09.2020;

Identyfikatory ORCID autorów: Ł. Dudziński - 0000-0002-8255-7608; D. Wysocki - 0000-0001-6144-0198; Ł. Czyżewski - 0000-0001-9473-9954;

Procentowy wkład merytoryczny: Ł. Dudziński - 70\%; D. Wysocki - 20\%; Ł. Czyżewski - 10\%;

Proszę cytować: SFT Vol. 56 Issue 2, 2020, pp. 110-125, https://doi.org/10.12845/sft.56.2.2020.7;

Artykuł udostępniany na licencji CC BY-SA 4.0 (https://creativecommons.org/licenses/by-sa/4.0/).

\section{Introduction}

Health hazards of officers of the State Fire Service (SFS) are mainly associated with rescue and firefighting activities. There are numerous risk factors and burdens during such operations. Worse still, they are intensified by various work conditions, time pressure and stress. Rescuers focused on saving lives, often put their own safety in second place.

Ensuring the safety of firefighters is extremely important, so that they can effectively perform their duties, maintain good condition and health - both during and after the service. In order to minimize the risk of health hazards during official duties personal protective equipment and protective clothing are used in the State Fire Service. There are also binding procedures, legal requirements in the form of acts, regulations and standards. Officers also take part in training courses in occupational health and safety (OHS). Everything that affects the safety of a firefighter's work must be of the highest quality, because this profession is classified as high-risk [1-3].

In addition to rescue works, firefighters perform many other duties which may lead to injuries or other health hazards. During their service, firefighters participate in trainings, exercises, undergo operational readiness inspections, perform equipment maintenance, participate in sports activities, and keep the barracks in order. All obligations translate into a large number of psychophysical burdens that are harmful or onerous to health. They are included in an annual referral for periodic firefighter examinations [4]:

- shift service,

- mental stress,

- night work,

- work at height,

- work in smoke,

- work in high and low temperatures,

- physical burden,

\section{Wstęp}

Zagrożenia zdrowotne funkcjonariuszy Państwowej Straży Pożarnej (PSP) kojarzone są głównie z prowadzeniem działań ratowniczo-gaśniczych. Czynników ryzyka i obciążeń podczas takich działań jest bardzo dużo. Dodatkowo potęgowane są przez pracę w różnych warunkach, presję czasu oraz stres. Ratownicy skupieni na ratowaniu życia często na drugim miejscu stawiają bezpieczeństwo własne.

Zapewnienie bezpieczeństwa strażaków jest niezwykle istotne, aby mogli oni skutecznie wykonywać swoje obowiązki oraz zachować dobrą kondycję i zdrowie - zarówno podczas służby, jak i po jej zakończeniu. W celu zminimalizowania ryzyka zagrożenia zdrowotnego podczas pełnienia obowiązków służbowych w PSP stosowany jest sprzęt ochrony osobistej oraz ubrania ochronne. Obowiązują również procedury postępowania, wymogi prawne w postaci ustaw, rozporządzeń i norm. Funkcjonariusze odbywają także szkolenia z bezpieczeństwa i higieny pracy (BHP). Wszystko, co wpływa na bezpieczeństwo pracy strażaka, musi charakteryzować się najwyższą jakością, ponieważ zawód ten jest kwalifikowany jako grupa wysokiego ryzyka [1-3].

Strażacy oprócz wyjazdów do zdarzeń wykonują wiele innych zadań, które mogą doprowadzić do kontuzji lub innego zagrożenia zdrowotnego. Podczas służby uczestniczą oni w szkoleniach, ćwiczeniach, przechodzą inspekcje gotowości operacyjnej, wykonują konserwacje sprzętu, biorą udział w zajęciach sportowych, dbają o porządek na terenie koszar. Wszystkie obowiązki przekładają się na znaczną ilość obciążeń psychofizycznych, które są szkodliwe lub uciążliwe dla zdrowia. Uwzględnia się je w corocznym skierowaniu na badania okresowe strażaka [4]:

- służba w systemie zmianowym,

- obciążenia psychiczne,

- praca w porze nocnej,

- praca na wysokości,

- praca w zadymieniu,

- praca w wysokich i niskich temperaturach, 
- contact with water,

- biological factors: viral hepatitis B and C, HIV virus, tetanus, tuberculosis, rabies, avian flu,

- chemical agents - smoke, carbon monoxide (CO), vapours,

- physical fitness tests.

The opinion of officers on health hazards related to, i.a., direct rescue operations is a source of knowledge that comes from practitioners - firefighters who, during rescue and firefighting operations and performing other official duties, are exposed to various threats and are subjected to extreme situations in reality. Information obtained directly from the officers of the combat division may contribute to the change in procedures and applied security measures. It can also be helpful in determining possible preventive actions reducing occupational risk.

\section{Material and methods}

The survey covered the officers of the State Fire Service serving in the combat division of the Rescue and Fire Fighting Units (RFFU) of the Lubelskie Voivodeship.

To achieve the aim of the study a diagnostic survey method was used. The research tool was the original questionnaire containing 16 questions. The survey was conducted from September to November 2019 at the Training Center of the Provincial Headquarters (PHTC) of the State Fire Service, where officers from all subordinate units undergo training, courses, thematic workshops, exams and recertifications in the field of qualified first aid (QFA). The results obtained from the questionnaire were analysed. The data of the officers was fully anonymous and participation in the survey was voluntary, of which the respondents had been informed. The selection of the group subjected to the study was random, not related to a specific shift in the service of the State Fire Service [1], [5].

\section{Survey characteristics}

Questions 1-5 ("about you") referred to: 1) age, 2) gender, 3) length of service in the State Fire Service, 4) type of command in which the respondent works (city / district), 5) character of service (commander / rescuer / driver ).

In questions 1 and 3 , the respondents were asked to choose values in time ranges, i.e.: the age of the respondents (Table 1) in ten-year ranges. The minimum value was the age of 20 years and the maximum value was over 50 years. The respondents could define their service experience (Table 2) in five-year ranges with a minimum value of less than 1 year and a maximum value of more than 25 years. Such a solution was applied after the suggestions of the respondents from the first group. The respondents asked not to provide exact values. In their opinion, such a solution provided a sense of greater anonymity.

Question 6 referred to an average number of rescue departures during a 24-hourservice. Questions 7-12 were based on a 5-point Likert scale and a point rating scale.
- obciążenie fizyczne,

- kontakt z wodą,

- czynniki biologiczne: wirusowe zapalenie wątroby (WZW) B i C, wirus HIV, tężec, gruźlica, wścieklizna, ptasia grypa,

- czynniki chemiczne - dym, tlenek węgla (CO), opary,

- testy sprawności fizycznej.

Opinia funkcjonariuszy na temat zagrożeń zdrowotnych związanych $\mathrm{m}$.in. z bezpośrednimi działaniami ratowniczymi jest źródłem wiedzy od praktyków - strażaków, którzy podczas działań ratowniczo-gaśniczych i realizowania innych obowiązków służbowych narażeni są na zróżnicowane zagrożenia i poddawani są ekstremalnym sytuacjom. Informacje uzyskane prosto od funkcjonariuszy podziału bojowego mogą wpłynąć na zmianę procedur i stosowanych środków bezpieczeństwa. Mogą również być pomocne w określeniu możliwych przedsięwzięć prewencyjnych zmniejszających ryzyko zawodowe.

\section{Materiał i metody}

Badaniem ankietowym objęto funkcjonariuszy PSP pełniących służbę w podziale bojowym jednostek ratowniczo-gaśniczych (JRG) województwa lubelskiego.

Do realizacji celu badania zastosowano metodę sondażu diagnostycznego. Narzędzie badawcze stanowił autorski kwestionariusz ankiety obejmujący 16 pytań. Badanie przeprowadzono w okresie od września do listopada 2019 roku w Ośrodku Szkolenia Komendy Wojewódzkiej (OSKW) PSP, gdzie funkcjonariusze ze wszystkich podległych jednostek odbywają szkolenia, kursy, warsztaty tematyczne, egzaminy i recertyfikację z zakresu kwalifikowanej pierwszej pomocy (KPP). Otrzymane wyniki poddano analizie. Dane funkcjonariuszy były w pełni anonimowe, a udział w badaniu dobrowolny, o czym poinformowano ankietowanych. Dobór grupy badawczej był losowy, niezwiązany z konkretną zmianą służbową PSP [1], [5].

\section{Charakterystyka ankiety}

Pytania 1-5 (metryczka) dotyczyły: 1) wieku, 2) płci, 3) stażu służby w PSP, 4) rodzaju komendy, w której ankietowany pełni służbę (komenda miejska/powiatowa), 5) pełnionego charakteru służby (dowódca/ratownik/kierowca).

W pytaniach 1 i 3 zaprezentowano ankietowanym do wyboru wartości w zakresach czasowych tj.: wiek ankietowanych (tabela 1) w dziesięcioletnich zakresach. Jako wartość minimalną przyjęto wiek do 20 lat, a maksymalną - powyżej 50 lat. Na pytanie o staż służby (tabela 2) można było udzielić odpowiedzi w pięcioletnich zakresach. Jako wartość minimalną ustalono okres poniżej 1 roku, natomiast maksymalną powyżej 25 lat. Taki zapis zastosowano po sugestiach samych ankietowanych z pierwszej grupy. Osoby badane prosiły, aby nie podawać dokładnych wartości. W ich ocenie takie rozwiązanie zapewniło poczucie większej anonimowości.

Pytanie 6 odnosiło się do średniej liczby wyjazdów ratowniczych w ciągu jednej dobowej służby. Z kolei pytania 7-12 oparte były na pięciostopniowej skali Likerta oraz punktowej skali oceny. 
Question 7 tackled the issue of health hazards that occurred during the service in the last 12 months. The hazards listed in Table 2 were presented to the respondents based on the safety data sheet of the State Fire Service firefighter [6]. The threats selected to the questionnaire were those deemed by the authors as the most frequent in the SFS service. The respondents could enter other health risks (not included in the table) under the item: "other (please write what)". The respondents could enter any type of threat that occurred in practice and the officer considers it real.

Question 8 referred to the activities which led to health risks, whereas question 9 referred to the probability of the occurrence of health hazards at the workplace listed in the table. In question 10, the respondents were asked to indicate the type of treatment that took place after the occurrence of one of the health risks mentioned in the survey. Question 11 was as follows: Do the currently used procedures of conduct during rescue and firefighting operations minimize the risk of health hazards? In question 12, the respondents were asked whether the currently used personal protective equipment minimize the risk of health hazards.

Questions 13-16 (single choice YES/NO, and in case of question 14 YES/NO/I DON'T know) included additional health burdens not related to professional duties and concerned:
- (13) smoking,
- (14) allergies,
- (15) chronic diseases,
- (16) medications taken on a regular basis.

\section{Description of the research area}

Organizational structure of the State Fire Service in the Lubelskie Voivodeship:

- provincial headquarters $(\mathrm{PH})$ with a training center,

- 4 city commands (CM),

- 16 district headquarters (DH).

More than 1,500 firefighters are on duty in the State Fire Service in the Lubelskie Voivodeship, of which 226 serve an eighthour duty and 1,367 work in shifts. In the Lubelskie Voivodeship, $\mathrm{CM}$ are located in cities with municipal rights (township district). The $\mathrm{CM}$ includes more than one rescue and fire fighting unit, respectively: Biała Podlaska -3 , Chełm -2 , Zamość -2 and Lublin as a voivodeship city - 6 [1], [7-8]. Randomly selected shift system officers constituted the sample group.

\section{Objective}

The aims of the study were as follows:

- an analysis of health threats in the combat division of the State Fire Service on the basis of theofficers' assessment;

- an analysis of occupational risk depending on the nature of the service performed in the combat division: commander, rescuer, driver - as assessed by officers.
Pytanie 7 dotyczyło zagrożeń zdrowotnych, które wystąpiły $u$ ankietowanego podczas pełnienia służby w ciągu ostatnich 12 miesięcy. Wymienione w tabeli 2 zagrożenia zostały zaczerpnięte z karty charakterystyki zagrożeń zawodowych strażaka PSP [6]. Wybrane zostały te, które w ocenie autorów występują podczas służby najczęściej. Jednocześnie, pozostawiono ankietowanym możliwość wpisania niewymienionego $w$ tabeli zagrożenia zdrowotnego pod pozycją „inne (proszę wpisać, jakie)”. Ankietowani mogli podać dowolny rodzaj zagrożenia, które wystąpiło lub występowało w praktyce, a funkcjonariusz uważa je za realne.

Pytanie 8 dotyczyło działań, podczas których wystąpiło zagrożenie zdrowotne. Pytanie 9 odnosiło się do prawdopodobieństwa wystąpienia wymienionych $\mathrm{w}$ tabeli zagrożeń zdrowotnych na swoim stanowisku pracy. W pytaniu 10 ankietowani proszeni byli o wskazanie rodzaju leczenia, które nastąpiło po wystąpieniu któregoś $z$ wymienionych $w$ ankiecie zagrożeń zdrowotnych. Pytanie 11 brzmiało: Czy stosowane obecnie procedury postępowania podczas działań ratowniczo-gaśniczych minimalizują ryzyko wystąpienia zagrożenia zdrowotnego? W pytaniu 12 poproszono o odpowiedź, czy stosowane obecnie środki ochrony osobistej podczas działań minimalizują ryzyko wystąpienia zagrożenia zdrowotnego.

Pytania 13-16 (jednokrotnego wyboru TAK/NIE, a w przypadku pytania 14 TAK/NIE/NIE WIEM) obejmowały dodatkowe obciążenia zdrowotne, niezwiązane z obowiązkami służbowymi i dotyczyły.

- (13) palenia papierosów,

- (14) alergii,

- (15) chorób przewlekłych,

- (16) przyjmowanych na stałe leków.

\section{Opis obszaru badań}

Struktura organizacyjna PSP w województwie lubelskim:

- komenda wojewódzka (KW) z ośrodkiem szkolenia,

- 4 komendy miejskie (KM),

- 16 komend powiatowych (KP).

W PSP $\mathrm{w}$ województwie lubelskim pełni służbę ponad 1500 strażaków, z czego 226 w systemie codziennym (ośmiogodzinnym), a 1367 w systemie zmianowym. Komendy miejskie na terenie województwa lubelskiego zlokalizowane są w miastach na prawach powiatu (powiatach grodzkich). W skład każdej KM wchodzi więcej niż jedna jednostka ratowniczo-gaśnicza (JRG), w: Białej Podlaskiej -3 , Chełmie - 2, Zamościu - 2 oraz Lublinie (jako mieście wojewódzkim) - 6 JRG [1], [7-8]. Grupę badawczą stanowili losowo wybrani funkcjonariusze systemu zmianowego.

Cel

Celem badania były:

- analiza zagrożeń zdrowotnych w podziale bojowym Państwowej Straży Pożarnej na podstawie ocen funkcjonariuszy;

- analiza ryzyka zawodowego w zależności od charakteru pełnionej służby w podziale bojowym: dowódca, ratownik, kierowca - na podstawie ocen funkcjonariuszy. 
For the purposes of the work, two research hypotheses were adopted:

1. The type of health risk differs depending on the function performed in the staff of the State Fire Service during rescue and firefighting operations (commander, rescuer, driver).

2. The currently adopted procedures and personal protective equipment during rescue and firefighting operations protect firefighters against bodily injuries and other health hazards and are assessed by firefighters as sufficient.

\section{Results}

$N=181$ officers of the State Fire Service took part in the survey: 180 men and 1 woman. The officers participating in the survey constituted $13.2 \%$ of all firefighters in the combat division of the Lubelskie Voivodeship, the number of which in the shift system is 1367 [9].

The results regarding the age and length of service are presented in Table 1 and Table 2
Na potrzeby realizacji pracy przyjęto dwie hipotezy badawcze:

1. Rodzaj zagrożenia zdrowotnego różni się w zależności od pełnionej funkcji w obsadzie zastępu PSP podczas działań ratowniczo-gaśniczych (dowódca, ratownik, kierowca).

2. Przyjęte obecnie procedury postępowania i środki ochrony osobistej podczas działań ratowniczo-gaśniczych dobrze zabezpieczają strażaków przed obrażeniami ciała i innymi zagrożeniami zdrowotnymi i są oceniane przez strażaków jako wystarczające.

\section{Wyniki}

W przeprowadzonym badaniu ankietowym wzięło udział 181 funkcjonariuszy PSP $(n=181)$. W badaniu uczestniczyli mężczyźni (180) i kobieta (1). Ankietowana grupa stanowiła 13,2\% wszystkich strażaków podziału bojowego województwa lubelskiego, których liczba w systemie zmianowym wynosi 1367 [9].

Wyniki dotyczące wieku i stażu służby przedstawiają tabele 1 oraz 2 .

Table 1. Age of respondents

Tabela 1. Wiek ankietowanych

\begin{tabular}{cccc}
\hline No. / Lp. & $\begin{array}{c}\text { Age of respondents in years } / \\
\text { Wiek ankietowanych w latach }\end{array}$ & $\begin{array}{c}\text { Number of officers / } \\
\text { Liczba funkcjonariuszy }\end{array}$ & $\begin{array}{c}\text { Percentage share in the sample group [\%] / } \\
\text { Udział procentowy w badanej grupie [\%] }\end{array}$ \\
\hline 1 & do 20 & 2 & 63 \\
\hline 2 & $21-30$ & 91 & 34.8 \\
\hline 3 & $31-40$ & 25 & 1.1 \\
\hline 4 & $41-50$ & 0 & 0 \\
\hline
\end{tabular}

Source / Źródło: Own elaboration / Opracowanie własne.

The most numerous group of respondents were officers aged $31-40(50.3 \%)$. No firefighter over 50 took part in the study.
Najliczniejszą grupę wśród badanych stanowiły osoby w wieku $31-40$ lat $(50,3 \%)$. W badaniu nie wziął udziału żaden strażak powyżej 50 roku życia.

Table 2. Service experience of the respondents in the State Fire Service Tabela 2. Staż służby ankietowanych w PSP

\begin{tabular}{|c|c|c|c|}
\hline No. / Lp. & $\begin{array}{l}\text { Service experience in the State Fire Service in years / } \\
\text { Staż służby w PSP w latach }\end{array}$ & $\begin{array}{l}\text { Number of officers / } \\
\text { Liczba funkcjonariuszy }\end{array}$ & $\begin{array}{l}\text { Percentage share in the sample group [\%]/ } \\
\text { Udział procentowy w badanej grupie [\%] }\end{array}$ \\
\hline 1 & $<1$ & 5 & 2.8 \\
\hline 2 & $1-5$ & 45 & 24.9 \\
\hline 3 & $6-10$ & 45 & 24.9 \\
\hline 4 & $11-15$ & 55 & 30.4 \\
\hline 5 & $16-20$ & 15 & 8.2 \\
\hline 6 & $21-25$ & 15 & 8.2 \\
\hline 7 & $>25$ & 1 & 0.6 \\
\hline
\end{tabular}

Source / Źródło: Own elaboration / Opracowanie własne. 
Firemen with 11-15 years of service experience dominated among the respondents. This value was chosen by $30.4 \%$ of the respondents. Only 1 firefighter had over 25 years of service.
Wśród ankietowanych dominowali strażacy ze stażem służby w zakresie 11-15 lat. Tę odpowiedź wybrało 30,4\% badanych. Tylko jeden ankietowany osiągnął staż służby powyżej 25 lat.

\section{Charakter służby pełnionej przez respondentów}

\section{The nature of the service performed by the respondents}

In question 4, the respondents were asked to indicate the nature of the service from the following: commander, rescuer, driver. In many firefighting and rescue units, firefighters perform different duties depending on the needs and human resources during the service, therefore a firefighter who is, for example, a driver during one service, during the next can act as a lifeguard in the crew. Similarly, in case of commanders, if there are more commanders than manned combat vehicles in one service, a commander with lower seniority or rank will man the vehicle as a rescuer. Therefore, in the question about the nature of the service performed, the word "most often" was added.

The most numerous group were SFS rescuers 92 (50.8\%), then commanders $58(32.1 \%)$, and drivers 31 (17.1\%). The results are presented in Figure 1.
W pytaniu 4 poproszono o wskazanie najczęściej pełnionej funkcji spośród wymienionych: dowódca, ratownik, kierowca. W wielu JRG strażacy wykonują różne obowiązki w zależności od potrzeb i możliwości kadrowych podczas służby, dlatego strażak, który jest np. kierowcą podczas jednej służby, podczas kolejnej może pełnić obowiązki ratownika w obsadzie zastępu. Przykładowo, gdy jest więcej dowódców niż wprowadzonych do podziału bojowego wozów, to dowódca z niższym stażem obsadza wóz jako ratownik. Dlatego w pytaniu o charakter pełnionej służby dodano słowo "najczęściej”.

Najliczniejszą grupę stanowili ratownicy PSP - 92 osoby $(50,8 \%)$, następnie dowódcy 58 osób $(32,1 \%)$, oraz kierowcy 31 osób $(17,1 \%)$. Wyniki prezentuje rycina 1 .

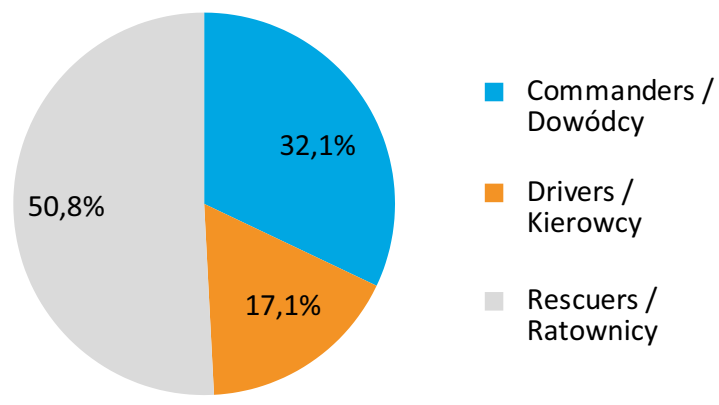

Figure 1. Percentage of commanders, rescuers and drivers of the State Fire Service in the sample group Rycina 1. Udział procentowy dowódców, ratowników i kierowców PSP w badanej grupie

Source / Źródło: Own elaboration / Opracowanie własne.

\section{Place of service}

In the analysed group of respondents, $58 \%$ served in one of the four MCs of the State Fire Service in the Lubelskie Voivodeship. The remaining $42 \%$ are officers from DH SFS. The results are graphically presented in Figure 2.

\section{Miejsce pełnienia służby}

W analizowanej grupie 58\% respondentów pełniło służbę w jednej z czterech KM PSP w województwie lubelskim. Pozostałe $42 \%$ to funkcjonariusze z KP PSP. Wyniki w sposób graficzny prezentuje rycina 2 .

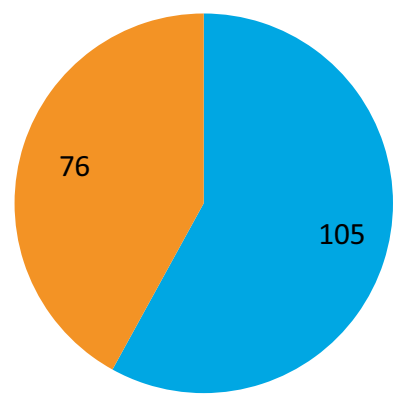

- City Command / Komenda Miejska PSP

- District Headquarter / Komenda Powiatowa PSP

Figure 2. Respondents' place of service

Rycina 2. Podział respondentów ze względu na miejsce pełnienia służby

Source / Źródło: Own elaboration / Opracowanie własne. 


\section{Daily number of departures}

The results for question 6 i.e. the number of interventions (rescue and firefighting departures) during one service are presented in Figure 3. Most of the respondents indicated 1, 2 or 3 rescue and firefighting operations during one service as the average in the last 12 months. No respondent indicated neither 9 nor more than 10 departures.

\section{Dobowa liczba wyjazdów}

Wyniki dotyczące pytania 6, tzn. liczby interwencji (wyjazdów ratowniczo-gaśniczych) podczas jednej służby, prezentuje rycina 3. Większość ankietowanych wskazało 1, 2 lub 3 wyjazdy ratowniczo-gaśnicze w ciągu jednej służby jako średnią w ostatnich 12 miesiącach. Żaden ankietowany nie wskazał w ciągu służby 9 wyjazdów ani więcej niż 10 wyjazdów.

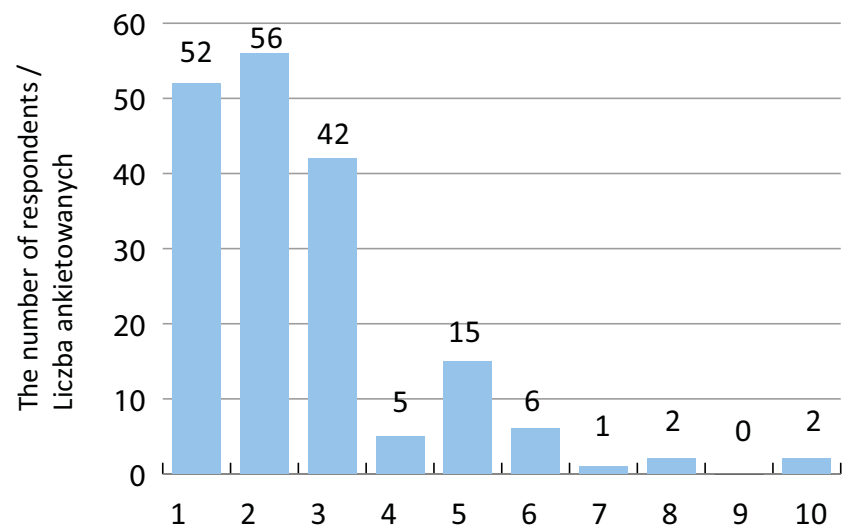

Average number of interventions in one day / Średnia liczba interwencji podczas jednej służby

Figure 3. Average number of departures as assessed by the respondents during one service in the last 12 months Rycina 3. Średnia liczba wyjazdów w ocenie ankietowanych podczas jednej służby w ciągu ostatnich 12 miesięcy Source / Źródło: Own elaboration / Opracowanie własne.

\section{Health threats during service in the last 12 months}

The results related to question 7 , in which the respondents were asked to indicate the estimated frequency of occurrence of certain health hazards during their service in the State Fire Service, are presented in Table 3. The results are presented by the nature of the service: commander, rescuer, driver.

\section{Zagrożenia zdrowotne podczas służby w ostatnich 12 miesiącach}

Wyniki odnoszące się do pytania 7, w którym poproszono respondentów o zaznaczenie szacunkowej częstotliwości występowania określonych zagrożeń dla zdrowia podczas służby w PSP, prezentuje tabela 3. Wyniki przedstawiono z podziałem na charakter pełnionej służby: dowódca, ratownik, kierowca.

\begin{tabular}{|c|c|c|c|c|c|c|c|c|}
\hline \multirow{2}{*}{\multicolumn{2}{|c|}{$\begin{array}{l}\text { Body injuries and others health risks / Obrażenia ciała } \\
\qquad \text { i inne zagrożenia zdrowotne }\end{array}$}} & \multicolumn{7}{|c|}{$\begin{array}{l}\text { Estimated number of threats in the last } 12 \text { months / } \\
\text { Szacunkowa liczba zagrożeń w ostatnich } 12 \text { miesiącach }\end{array}$} \\
\hline & & 0 & 1 & $2-4$ & $5-10$ & $11-15$ & $>15$ & Total / Suma \\
\hline \multirow{4}{*}{$\begin{array}{l}\text { Damage in the system } \\
\text { bone-skeletal / Uszkodze- } \\
\text { nia w układzie kostno- } \\
\text { szkieletowym }\end{array}$} & Rescuer / Ratownik & 65 & 19 & 7 & 0 & 1 & 0 & 92 \\
\hline & Commander / Dowódca & 36 & 7 & 12 & 2 & 1 & 0 & 58 \\
\hline & Driver / Kierowca & 20 & 4 & 7 & 0 & 0 & 0 & 31 \\
\hline & Total & 121 & 30 & 26 & 2 & 2 & 0 & 181 \\
\hline \multirow{4}{*}{$\begin{array}{l}\text { Contusions / } \\
\text { Stłuczenia }\end{array}$} & Rescuer / Ratownik & 63 & 10 & 5 & 9 & 1 & 4 & 92 \\
\hline & Commander / Dowódca & 22 & 12 & 14 & 5 & 4 & 1 & 58 \\
\hline & Driver / Kierowca & 14 & 9 & 2 & 4 & 0 & 2 & 31 \\
\hline & Total / Suma & 99 & 31 & 21 & 18 & 5 & 7 & 181 \\
\hline
\end{tabular}




\begin{tabular}{|c|c|c|c|c|c|c|c|c|}
\hline \multirow{4}{*}{ Stress / Stres } & Rescuer / Ratownik & 58 & 13 & 14 & 4 & 0 & 3 & 92 \\
\hline & Commander / Dowódca & 25 & 6 & 12 & 7 & 5 & 3 & 58 \\
\hline & Driver / Kierowca & 14 & 9 & 5 & 2 & 1 & 0 & 31 \\
\hline & Total / Suma & 97 & 28 & 31 & 13 & 6 & 6 & 181 \\
\hline \multirow{4}{*}{ Burns / Oparzenia } & Rescuer / Ratownik & 71 & 12 & 8 & 1 & 0 & 0 & 92 \\
\hline & Commander / Dowódca & 39 & 1 & 10 & 7 & 0 & 0 & 57 \\
\hline & Driver / Kierowca & 21 & 3 & 6 & 1 & 0 & 0 & 31 \\
\hline & Total / Suma & 131 & 16 & 24 & 9 & $\mathbf{0}$ & 0 & 180 \\
\hline \multirow{4}{*}{ Wounds / Rany } & Rescuer / Ratownik & 81 & 6 & 4 & 1 & 0 & 0 & 92 \\
\hline & Commander / Dowódca & 48 & 3 & 5 & 2 & 0 & 0 & 58 \\
\hline & Driver / Kierowca & 24 & 4 & 2 & 1 & 0 & 0 & 31 \\
\hline & Total / Suma & 153 & 13 & 11 & 4 & 0 & 0 & 181 \\
\hline \multirow{4}{*}{$\begin{array}{c}\text { Exposure to } \\
\text { inhalation poisoning / } \\
\text { Narażenie na zatrucie } \\
\text { wziewne }\end{array}$} & Rescuer / Ratownik & 82 & 1 & 7 & 2 & 0 & 0 & 92 \\
\hline & Commander / Dowódca & 49 & 4 & 0 & 3 & 1 & 1 & 58 \\
\hline & Driver / Kierowca & 25 & 3 & 2 & 1 & 0 & 0 & 31 \\
\hline & Total / Suma & 156 & 8 & 9 & 6 & 1 & 1 & 181 \\
\hline \multirow{4}{*}{$\begin{array}{l}\text { Injury to the } \\
\text { eyeball / Obrażenia } \\
\text { gałki ocznej }\end{array}$} & Rescuer / Ratownik & 89 & 1 & 1 & 1 & 0 & 0 & 92 \\
\hline & Commander / Dowódca & 50 & 5 & 3 & 0 & 0 & 0 & 58 \\
\hline & Driver / Kierowca & 30 & 1 & 0 & 0 & 0 & 0 & 31 \\
\hline & Total / Suma & 169 & 7 & 4 & 1 & 0 & 0 & 181 \\
\hline \multirow{4}{*}{ Allergies / Alergie } & Rescuer / Ratownik & 82 & 7 & 2 & 1 & 0 & 0 & 92 \\
\hline & Commander / Dowódca & 46 & 3 & 4 & 1 & 4 & 0 & 58 \\
\hline & Driver / Kierowca & 23 & 2 & 5 & 1 & 0 & 0 & 31 \\
\hline & Total / Suma & 151 & 12 & 11 & 3 & 4 & 0 & 181 \\
\hline
\end{tabular}

Other (please enter what) /

Inne (proszę wpisać, jakie) 
Damage to the skeletal system were experienced by 30 firefighters, including 19 rescuers, once in the year preceding the survey. From 2 to 4 injuries happened to 26 firefighters (12 of them were commanders). No firefighter declared more than 15 sprains/fractures per year.

The contusions that occurred 2-4 times a year concerned 21 (11.6\%) firefighters (including 14 rescuers, 5 commanders, 2 drivers). Bruises over 15 a year were declared by 7 (3.9\%) firefighters (4 rescuers, 1 commander, 2 drivers).

Reactions to stress that repeated 2-4 times a year occurred in 31 (17.1\%) firefighters (14 rescuers, 12 commanders and 5 drivers), while 6 (3.3\%) officers ( 3 rescuers, 3 drivers) declared more than 15 times a year.

Burns in the number from 5 to 10 annually were declared by 9 (5\%) respondents, including 1 rescuer, 7 commanders and 1 driver.

Moreover, three officers chose the answer "Other", entering accordingly:

- "overheating of the body",

- "hypertension",

- "lack of comfort while operating in protective clothing (pressure)".

\section{Professional duties and health risk}

The respondents were asked to assess the frequency of health hazards which occurred during their service related to both rescue and firefighting activities and other official duties. The frequency of injuries / health threats in relation to specific types of activities was rated on a 5-point scale (RARE $1-2-3-4-5$ OFTEN). The results are presented in Table 4.
Uszkodzeń w układzie kostno-szkieletowym doświadczyło 30 strażaków, w tym 19 ratowników, jeden raz w ciągu roku poprzedzającego badanie. Od 2 do 4 urazów wystąpiło w tym okresie u 26 strażaków (12 spośród nich to dowódcy). Powyżej 15 skręceń/złamań rocznie nie deklarował żaden strażak.

Stłuczenia występujące $2-4$ razy w roku dotyczyły 21 (11,6\%) strażaków (w tym 14 ratowników, 5 dowódców, 2 kierowców). Stłuczenia w liczbie powyżej 15 rocznie deklarowało 7 (3,9\%) strażaków (4 ratowników, 1 dowódca, 2 kierowców).

Reakcje na stres powtarzające się od 2 do 4 razy w roku wystąpiły u 31 (17,1\%) strażaków (14 ratowników, 12 dowódców i 5 kierowców), natomiast powyżej 15 razy w ciągu roku u 6 funkcjonariuszy (3,3\%, w tym 3 ratowników i 3 kierowców).

Oparzenia w liczbie od 5 do 10 rocznie zadeklarowało 9 ankietowanych (5\%), w tym 1 ratownik, 7 dowódców i 1 kierowca.

Ponadto trzech funkcjonariuszy wybrało odpowiedź „inne”, wpisując odpowiednio:

- „przegrzanie organizmu”,

- "nadciśnienie”,

- „brak wygody podczas działania w ubraniu ochronnym (ucisk)".

\section{Obowiązki służbowe a zagrożenie zdrowotne}

Ankietowanych poproszono o ocenę częstotliwości występowania zagrożeń zdrowotnych związanych zarówno z działaniami ratowniczo-gaśniczymi, jak i innymi obowiązkami służbowymi. Częstotliwość obrażeń ciała/zagrożeń zdrowotnych w odniesieniu do konkretnych rodzajów działań ankietowani oceniali w pięciostopniowej skali (RZADKO $1-2-3-4-5$ CZĘSTO). Wyniki prezentuje tabela 4.

Table 4. Type of activities in which health hazards of firefighters occurred in the combat division in the last 12 months Tabela 4. Częstotliwość poszczególnych rodzajów zagrożeń zdrowotnych strażaków służących w podziale bojowym w ostatnich 12 miesiącach poprzedzających badanie

\begin{tabular}{|c|c|c|c|c|c|}
\hline \multirow{2}{*}{$\begin{array}{c}\text { Type of action (percentage) / } \\
\text { Rodzaj działania (udział procentowy) }\end{array}$} & \multicolumn{5}{|c|}{ Frequency (1-5) / Częstotliwość występowania (1-5) } \\
\hline & 1 & 2 & 3 & 4 & 5 \\
\hline Firefighting activities (\%) / Działania gaśnicze (\%) & $28(15.5)$ & $50(27.6)$ & $59(32.6)$ & $24(13.3)$ & $20(11)$ \\
\hline Traffic accidents (\%) / Wypadki komunikacyjne (\%) & $40(22.1)$ & $49(27.1)$ & $62(34.3)$ & $18(9.9)$ & $12(6.6)$ \\
\hline Windbreaks (\%) / Wiatrołomy (\%) & $53(29.3)$ & $50(27.6)$ & $49(27.1)$ & $23(12.7)$ & $6(3.3)$ \\
\hline Other local threats (\%) / Inne miejscowe zagrożenia (\%) & $49(27.1)$ & $62(34.3)$ & $45(24.9)$ & $18(9.9)$ & $7(3.9)$ \\
\hline Demolition works (\%) / Prace rozbiórkowe (\%) & $57(31.5)$ & $60(33.1)$ & $44(24.3)$ & $17(9.4)$ & $3(1.7)$ \\
\hline Sports (\%) / Zajęcia sportowe (\%) & $75(41.4)$ & $34(18.8)$ & $40(22.1)$ & $18(9.9)$ & $14(7.7)$ \\
\hline Training classes (\%) / Zajęcia szkoleniowe (\%) & $117(64.6)$ & $31(17.1)$ & $15(8.3)$ & $13(7.2)$ & $5(2.8)$ \\
\hline $\begin{array}{l}\text { Operational readiness inspections (\%) / } \\
\text { Inspekcje gotowości operacyjnej (\%) }\end{array}$ & $108(59.7)$ & $38(21.0)$ & $16(8.8)$ & $10(5.5)$ & $9(5.0)$ \\
\hline $\begin{array}{l}\text { Others in SRG action }(\%) \text { * / Inne w ramach działań } \\
\text { SGR PSP* (\%) }\end{array}$ & $105(58)$ & $34(18.8)$ & $35(19.3)$ & $4(2.2)$ & $3(1.6)$ \\
\hline
\end{tabular}

Source / Źródło: Own elaboration / Opracowanie własne.

* Specialist SFS Rescue Group (SRG) - larger units of SFS rescuers dispatched to the scene when the local forces and resources at the SFS Command Post (CP) are insufficient. In the Lubelskie Voivodeship, there are several SRG units with different specializations: chemical-ecological, altitude, technical, water-diving, search and rescue [10-11]./ * Specjalistyczna Grupa Ratownicza PSP - większe pododdziały ratowników PSP dysponowanych do zdarzeń, w przypadku gdy lokalne siły i środki dysponowane przez Stanowisko Kierowania (SK) PSP są niewystarczające. W województwie lubelskim funkcjonuje kilka SGR o różnych specjalizacjach: chemiczno-ekologiczna, wysokościowa, techniczna, wodno-nurkowa, poszukiwawczo-ratownicza [10-11]. 
It was shown that firefighting activities were associated with the highest risk of health hazards - they concerned 20 (11.0\%) firefighters. Sports activities were assessed by 14 (7.7\%) firefighters as often conducive to injuries.

The lowest risk was attributed to the operational readiness inspections of 108 (59.7\%) officers and training classes 117 (64.6\%), but the survey did not divide into practical and theoretical training classes, which explains the good result in the assessment of the respondents.

\section{Treatment of the resulting health risks}

The respondents were asked to indicate the type of treatment, if it took place after the occurrence of a health risk. The type of treatment and frequency of occurrence were selected by the respondents from those given in a table according to a 5-point scale: 1 - did not occur, 2 - was rare, 3 - was common, 4 - was most common, 5 - was always present. The results are presented in Table 5.
Wykazano, że działania gaśnicze były obciążone największym ryzykiem wystąpienia zagrożeń zdrowotnych - dotyczyły 20 (11,0\%) strażaków. Zajęcia sportowe zostały ocenione przez 14 (7,7\%) strażaków jako często sprzyjające kontuzjom. Najmniejszym ryzykiem były obciążone inspekcje gotowości operacyjnej (wykazało to 108 funkcjonariuszy $-59,7 \%$ grupy) i zajęcia szkoleniowe (117 strażaków, 64,6\% grupy). Należy przy tym dodać, że w ankiecie nie dokonano podziału na zajęcia szkoleniowe praktyczne i teoretyczne, co tłumaczy dobry wynik w ocenie respondentów.

\section{Leczenie powstałych zagrożeń zdrowotnych}

Ankietowanych poproszono o wskazanie rodzaju leczenia, jeśli takie przechodzili po wystąpieniu zagrożenia zdrowotnego. Do każdego rodzaju przypisywali częstotliwość według pięciostopniowej skali: 1 - nie wystąpiło, 2 - występowało rzadko, 3 występowało często, 4 - występowało w większości, 5 - występowało zawsze. Wyniki zaprezentowane są w tabeli 5 .

Table 5. Types of treatment indicated by officers that occurred as a result of the health hazards (listed in Table 3)

Tabela 5. Odpowiedzi funkcjonariuszy na pytanie o rodzaj leczenia w wyniku powstałych u nich zagrożeń zdrowia (wymienionych w tabeli 3)

\begin{tabular}{|c|c|c|c|c|c|}
\hline \multirow{3}{*}{ Type of treatment / Rodzaj leczenia } & \multicolumn{5}{|c|}{$\begin{array}{c}\text { Percentage / Częstotliwość } \\
\text { Liczba odpowiedzi (Procent ankietowanych) }\end{array}$} \\
\hline & 1 & 2 & 3 & 4 & 5 \\
\hline & $\begin{array}{l}\text { Not occured / } \\
\text { Nie wystąpiło }\end{array}$ & Rarely / Rzadko & Often / Często & Mostly / W większości & Always / Zawsze \\
\hline Homemade (\%) / Domowe & $100(55.2)$ & $44(24.3)$ & $18(9.9)$ & $14(7.7)$ & $5(2.8)$ \\
\hline Outpatient (\%) / Ambulatoryjne & $136(75.1)$ & $25(13.8)$ & $10(5.5)$ & $3(1.7)$ & $7(3.9)$ \\
\hline Inpatient (\%) / Szpitalne & $151(83.4)$ & $23(12.7)$ & $2(1.1)$ & $2(1.1)$ & $3(1.7)$ \\
\hline Treatment (\%) / Zabiegowe & $150(82.9)$ & $21(11.6)$ & $5(2.8)$ & $1(0.6)$ & $4(2.2)$ \\
\hline
\end{tabular}

Source / Źródło: Own elaboration / Opracowanie własne.

As a result of health hazards on the job, 5 firefighters indicated home treatment $(2.8 \%)$ as the most common type of treatment, 7 (3.9\%) outpatient treatment, and $3(1.7 \%)$ inpatient treatment. The answer "did not occur" was indicated by 100 respondents $(55.2 \%)$ in case of home treatment, 136 (75.1\%) in case of outpatient consultations, 151 (83.4\%) in the case of inpatient treatment, and $150(82.9 \%)$ in case of surgical treatment. At the same time, as the respondents rightly noticed, minor procedures are also possible as part of outpatient treatment. The survey made it possible to select the frequency of occurrence of each type of treatment separately, individual responses were not related to each other.
W wyniku zagrożenia zdrowia na służbie jako najczęstszy rodzaj leczenia 5 strażaków wskazało kuracje domowe (2,8\%), $7(3,9 \%)$ leczenie ambulatoryjne, a $3(1,7 \%)$ szpitalne. Leczenie szpitalne zabiegowe jako najczęstszą formę terapii zadeklarowało 4 funkcjonariuszy (2,2\%). Odpowiedź "nie wystąpiło" na pytanie o leczenie domowe wybrało 100 ankietowanych $(55,2 \%)$. Tę samą odpowiedź 136 strażaków $(75,1)$ wskazało w przypadku porady ambulatoryjnej, 151 badanych $(83,4 \%)$ odnośnie do pobytu w szpitalu, a 150 badanych $(82,9 \%)$ w stosunku do leczenia zabiegowego. Przy czym - jak słusznie zauważyli sami ankietowani - drobne zabiegi możliwe są również w ramach procedur ambulatoryjnych. Ankieta umożliwiała wybór częstotliwości występowania każdego rodzaju leczenia osobno, poszczególne odpowiedzi nie były ze sobą powiązane. 


\section{Procedures vs safety during rescue and firefighting operations}

In the next two questions, the respondents expressed their opinion on health risks according to a 5-point scale:

- -2 - strongly disagree

- -1 - rather disagree,

- 0 - have no opinion

- +1 - rather agree,

- +2 - definitely agree.

The respondents expressed their opinion on the question: do the adopted procedures during rescue and firefighting activities minimize the risk of health hazards? The results are presented in Figure 4.

\section{Procedury a bezpieczeństwo podczas działań ratowniczo-gaśniczych}

W kolejnych dwóch pytaniach ankietowani wyrażali swoją opinię na temat zagrożeń zdrowotnych według pięciostopniowej skali:

- -2 - zdecydowanie się nie zgadzam,

- -1 - raczej się nie zgadzam,

- 0 - nie mam zdania

- $\quad+1$ - raczej się zgadzam,

- +2 - zdecydowanie się zgadzam.

Ankietowani odpowiedzieli na następujące pytanie: „Czy przyjęte procedury postępowania podczas działań ratowniczo-gaśniczych minimalizują ryzyko wystąpienia zagrożenia zdrowotnego"? Wyniki prezentuje rycina 4.

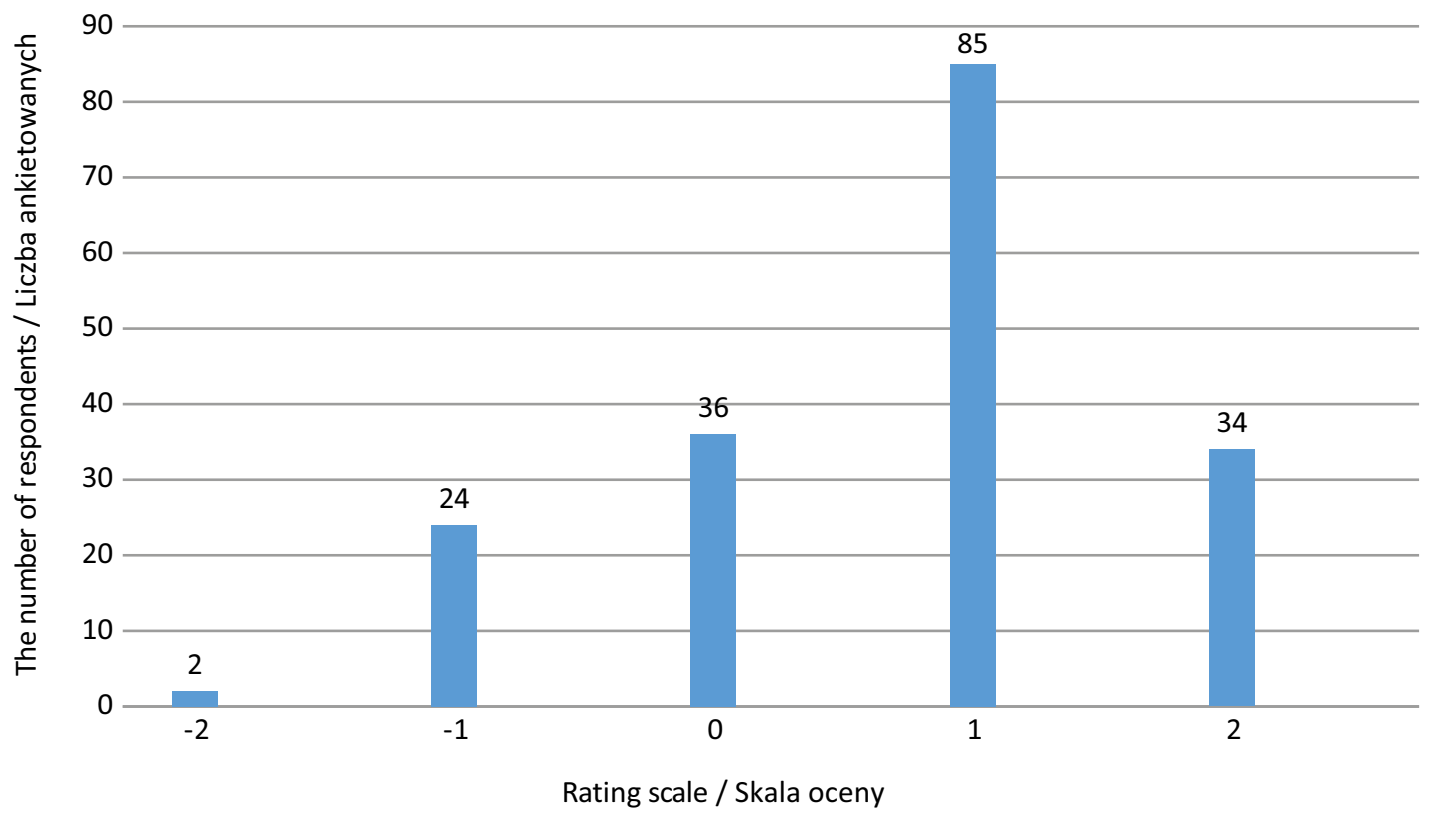

Figure 4. Respondents' opinion on the effectiveness of procedures in minimizing the risk of health hazards during rescue activities Rycina 4. Opinia ankietowanych na temat skuteczności procedur postępowania mających na celu minimalizację ryzyka zagrożenia zdrowia podczas działań Source / Źródło: Own elaboration / Opracowanie własne.

The analysis of the respondents' choices showed that the majority of them positively assessed the procedures adopted in the State Fire Service. A positive answer $(+1,+2)$ was given by a total of 119 officers. 26 people expressed a negative opinion on the adopted procedures (answers $-2,-1$ ) and they constitute $14.3 \%$ of the respondents.

\section{Personal protection measures and the safety of rescue and firefighting activities}

Figure 5 illustrates responses of the respondents to the question: "Does the personal protective equipment currently used in the State Fire Service minimize the risk of health hazards?"
Analiza wskazań respondentów pozwala stwierdzić, że większość pozytywnie ocenia przyjęte procedury postępowania w PSP. Odpowiedź pozytywną $(+1,+2)$ dało w sumie 119 funkcjonariuszy. 26 osób wyraziło negatywną opinię na temat przyjętych procedur postępowania (odpowiedzi -2, -1) i stanowią łącznie $14,3 \%$ ankietowanych.

\section{Środki ochrony osobistej a bezpieczeństwo działań ratowniczo-gaśniczych}

Rycina 5 prezentuje odpowiedzi respondentów na pytanie: „Czy stosowane obecnie w PSP środki ochrony osobistej podczas działań ratowniczo-gaśniczych minimalizują ryzyko wystąpienia zagrożenia zdrowotnego?" 


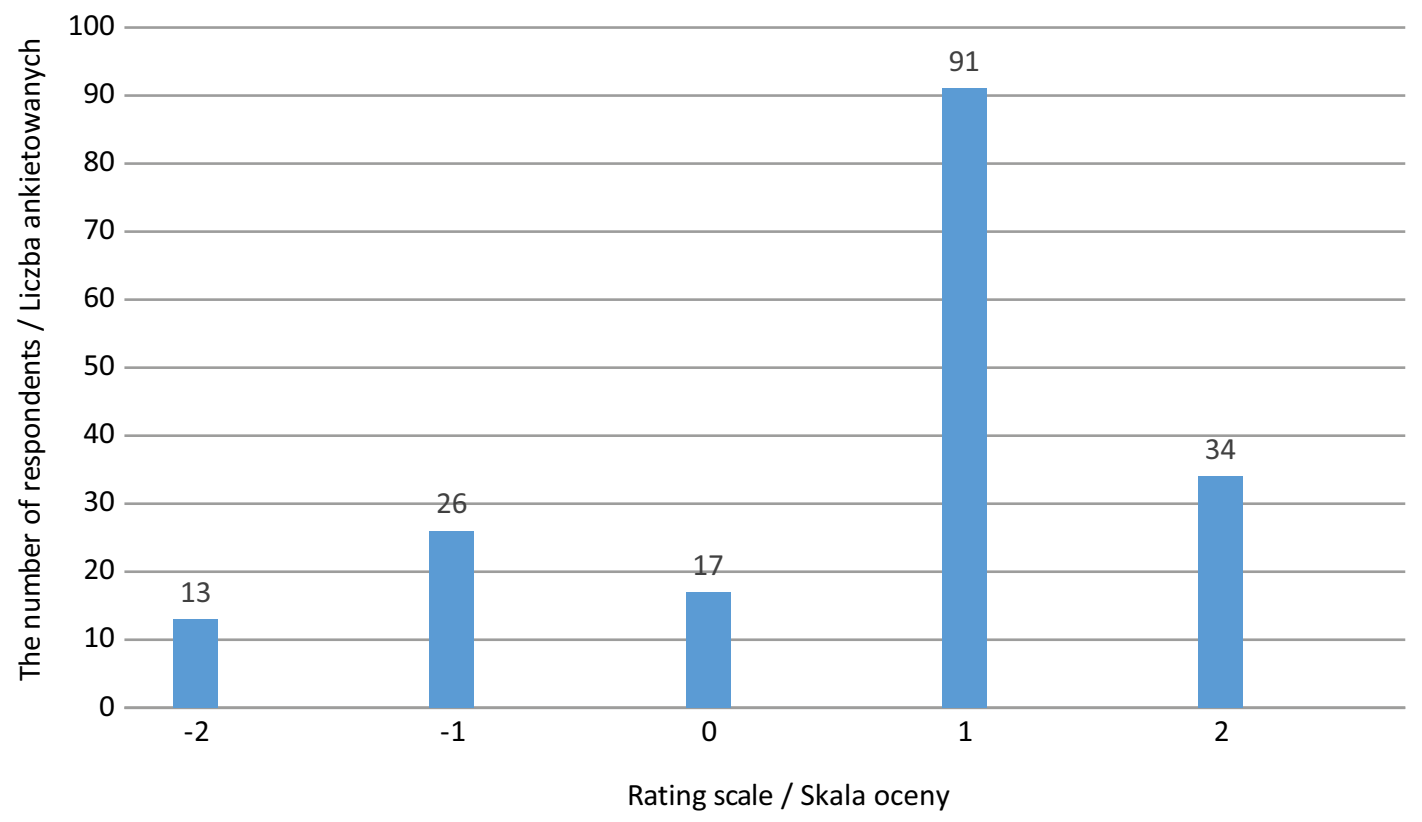

Figure 5. Respondents' opinion on the effectiveness of personal protective equipment in minimizing the risk of health hazards during rescue activities Rycina 5. Opinia ankietowanych na temat skuteczności środków ochrony osobistej w minimalizacji ryzyka zagrożenia zdrowia podczas działań

Source /Źródło: Own elaboration / Opracowanie własne.

In total, 125 respondents, constituting $69 \%$ of the entire sample, express a positive opinion on the personal protective equipment used in the State Fire Service. For 39 (21\%) officers personal protective equipment does not ensure adequate safety during rescue operations.

\section{Summary}

The aim of the study was to analyze the health hazards of officers in the combat division of the State Fire Service from the perspective of the firefighters themselves. The study found that exposure to different health hazards among officers - regardless the nature of their service (commander, rescuer, driver) - is at a similar level. These hazards involve both personal injuries (sprains, fractures, burns) and non-traumatic hazards (e.g. reactions to stress).

The assessment of the service as stressful, according to the respondents occupying individual positions in the State Fire Service, is at a similar level. One stressful situation in the last 12 months was indicated by 13 rescuers, 6 commanders, 9 drivers, and 5 to 10 stressful situations per year were indicated by 4 rescuers, 7 commanders, 2 drivers. Indication of stress during the service by respondents occupying various positions in the State Fire Service results from the fact that each position is associated with particular duties and responsibilities. A driver drives a heavy fire vehicle in an emergency mode. He is responsible for the safety of the crew, the technical condition of expensive equipment. He must watch out for unusual reactions of other road users. A rescuer in the State Fire Service is the person who works directly in the danger zone, being closest to the danger,
W sumie 125 respondentów, stanowiących 69\% ogółu badanych, wyraża pozytywną opinię na temat środków ochrony osobistej stosowanych w PSP. Z kolei 39 (21\% wszystkich ankietowanych) uważa, że środki ochrony osobistej nie zapewniają odpowiedniego bezpieczeństwa podczas działań.

\section{Podsumowanie}

Celem badania była analiza zagrożeń zdrowotnych dla funkcjonariuszy podziału bojowego PSP z perspektywy samych strażaków. Badanie wykonano z zastosowaniem metody ankietowej. Stwierdzono, że narażenie na wybrane zagrożenia zdrowotne poszczególnych grup strażaków - niezależnie od charakteru pełnionej służby (dowódca, ratownik, kierowca) - kształtuje się na podobnym poziomie. Zagrożenia te dotyczą zarówno obrażeń ciała (skręcenia, złamania, oparzenia), jak i problemów nieurazowych (np. reakcje na stres). Podobnie ocena służby jako stresującej przez ankietowanych zajmujących poszczególne stanowiska w PSP jest bardzo zbliżona. Jedną sytuację stresową w ostatnich 12 miesiącach wskazało 13 ratowników, 6 dowódców i 9 kierowców. Od 5 do 10 sytuacji stresowych rocznie zadeklarowało 4 ratowników, 7 dowódców i 2 kierowców. Potwierdzenie obecności stresu podczas służby przez ankietowanych zajmujących różne stanowiska w PSP można wytłumaczyć tym, że każdy ma swoje obowiązki i przypisaną do nich odpowiedzialność. Kierowca prowadzi ciężkie auto pożarnicze. Jeździ w trybie alarmowym i odpowiada za bezpieczeństwo załogi, stan techniczny kosztownego sprzętu. Dodatkowo musi uważać na nietypowe reakcje innych uczestników ruchu. Ratownik w PSP jest osobą, która działa bezpośrednio w strefie zagrożenia. Znajduje się najbliżej jego źródła 
potentially bearing the greatest risk of losing health. A commander also operating in the danger zone is responsible for the manner and effectiveness of rescue and firefighting operations, for the safety of his crew. He corresponds with the SK, cooperates with other services, prepares reports on rescue actions, which are often the subject of later analysis.

However, in the opinion of the respondents, stress is not the dominant health problem. Only 3 rescuers and 3 commanders showed more than 15 stressful situations per year. As indicated by the State Sanitary Inspection of the Ministry of Interior and Administration, based on the results of research obtained by the Institute of Occupational Medicine in Łódź [12], stress in the work of firefighters is a constant exposure related to the daily requirements of the service. Less frequently, it takes the form of traumatic stress as a result of critical events. After such events, the technique of critical incident stress debriefing is often practiced. It is a method of psychological help. It should be added here that PH SFS Lublin employs a psychologist to work with officers of the State Fire Service, but the questions regarding psychological help of respondents now or in the past has not been analysed.

Interesting are the respondents' answers concerning the health risk in the form of burns (Table 3, burns). Currently, fires are not the most common type of threat to which the State Fire Service is dispatched, as the name of the uniformed formation might suggest. Therefore, in the opinion of the respondents, burns are not the dominant or one of the most frequent health threats. The low rate of burns among the respondents during the service is due to the high-quality protective equipment, procedures adopted during firefighting. It also results from the statistics of rescue and firefighting operations for the Lubelskie voivodship and for the entire territory of Poland presented on the example of 2018 in Table 6. i potencjalnie ponosi największe ryzyko utraty zdrowia. Dowódca, również działający w strefie zagrożenia, ponosi odpowiedzialność za sposób i skuteczność prowadzenia działań ratowniczo-gaśniczych, za bezpieczeństwo swojej załogi. Prowadzi także korespondencję z SK, współpracuje z innymi służbami, sporządza meldunki z wyjazdów, które są często przedmiotem późniejszej analizy.

Jednak w ocenie ankietowanych stres nie jest dominującym problemem zdrowotnym. Powyżej 15 sytuacji stresowych rocznie wykazało tylko 3 ratowników i 3 dowódców. Jak wskazuje Państwowa Inspekcja Sanitarna MSWiA na podstawie wyników badań uzyskanych przez Instytut Medycyny Pracy w Łodzi [12] stres w pracy strażaków jest narażeniem ciągłym, związanym z codziennymi wymaganiami służby. Rzadziej przyjmuje formę stresu traumatycznego wskutek zdarzeń krytycznych. Po tego typu zdarzeniach często praktykuje się technikę ponownego omówienia zdarzenia krytycznego - debriefing (ang. critical incident stress debriefing). Jest to metoda pomocy psychologicznej. Należy w tym miejscu dodać, że KW PSP Lublin zatrudnia psychologa do pracy z funkcjonariuszami PSP, jednak pytania dotyczące pomocy psychologicznej respondentów obecnie lub w przeszłości nie były przedmiotem analizy.

Ciekawe okazują się odpowiedzi respondentów na temat zagrożenia zdrowia ankietowanych w postaci oparzeń (tabela 3 , oparzenia). Pożary nie są obecnie najczęstszym rodzajem zagrożeń, do których dysponowana jest PSP, (inaczej niż wskazuje to nazwa formacji umundurowanej). Wobec tego oparzenia w ocenie ankietowanych nie są dominującym lub jednym z częstszych zagrożeń zdrowotnych. Niski wskaźnik oparzeń wśród ankietowanych podczas służby jest zasługą wysokiej jakości sprzętu ochronnego, przyjętych procedur postępowania podczas gaszenia pożarów, ale również wynika ze statystyk wyjazdów jednostek ratowniczo-gaśniczych dla woj. lubelskiego i całej Polski zaprezentowanych na przykładzie 2018 roku w tabeli 6 .

Table 6. Types of rescue and firefighting events in 2018

Tabela 6. Podział na rodzaj zdarzeń ratowniczo-gaśniczych w 2018 roku

\begin{tabular}{lcc}
\hline $\mathbf{2 0 1 8}$ year / $\mathbf{2 0 1 8}$ rok & $\begin{array}{c}\text { All events in the thousands / } \\
\text { Wszystkie zdarzenia } \\
\text { [w tysiącach] }\end{array}$ & $\begin{array}{c}\text { Local Threats in the thousands / } \\
\text { Miejscowe zagrożenia } \\
\text { [w tysiącach] }\end{array}$ \\
\hline Whole Poland / Cała Polska & 502 & 354 \\
\hline Lublin voivodeship / Lubelskie & 21 & 13,6 \\
[w tysiącach]
\end{tabular}

Source /Źródło: Dane statystyczne KG PSP, https://danepubliczne.gov.pl/ organization/komenda-glowna-panstwowej-strazy-pozarnej [13].

A. Pawlak et al. [14] in a publication from 2016 analysing accidents in the work environment of SFS firefighters noted that the State Fire Service officers, due to the specific nature of their work and a wide range of hazards, are more likely than other professional groups to be at risk of accidents at work. The group most exposed to accidents in this profession are firefighters working in rescue and firefighting units. The results obtained by the authors partially coincide with the results of this analysis in terms
A. Pawlak i wsp. [14] w publikacji z 2016 roku analizującej wypadki w środowisku pracy strażaków PSP zauważyli, że funkcjonariusze Państwowej Straży Pożarnej (PSP) ze względu na specyfikę pracy i szeroki wachlarz zagrożeń częściej niż inne grupy zawodowe są narażeni na ryzyko wystąpienia wypadku przy pracy. Grupą najbardziej narażoną na wypadki w zawodzie strażaka są czynni strażacy, pracujący w jednostkach ratowniczo-gaśniczych. Uzyskane przez tych autorów wyniki częściowo pokrywają się 
of sports activities as a common cause of injuries. In the aforementioned publication, the dominant cause of events was incorrect behaviour or carelessness. The most common injuries from accidents were multiple fractures, bone fractures and sprains. However, safety during sports activities is not only influenced by caution. It is of great importance to perform an appropriate warm-up for a given activity. The infrastructure and sports equipment used for a given exercise also play a key role. In the authors' opinion, the technical condition of the facilities and equipment used for broadly understood sports activities (including fire sports, individual sports and team sports) often leaves much to be desired. Since "sports activities" category was included in the survey (see Table 4) only in general terms, a thorough analysis of sports activities as exposure to health risks should be the subject of future research.

M. Wejnman et al. in a publication of 2013 [15] and W. Andruszkiewicz et al. in the publication of 2011 [16] describe the firefighter profession as classified to the group with a very high risk level. While performing their professional duties, firefighters are often exposed to considerable workload which adversely affects their health and is often life threatening. Moreover, the authors mention factors harmful to the health of firefighters: air pollution, noise, physical stress, occupational stress, changing daily work rhythm, working at heights, activities in the SGR. Most of the listed threats coincide with these analysed in this paper (Table 3 ).

In addition, Kokot Góra S. et al. in a publication of 2019 [17], as well as GK LeMasters et al. in a study of 2006 [18] analysed the health risks of officers. The authors enumerated worrying trends in the area of cancer incidence among firefighters and smoke hazards - both from a firefighting and health perspective. Hazardous substances that arise as a result of an uncontrolled combustion process, including toxic and carcinogenic substances, have not yet been fully identified.

\section{Conclusions}

The analysis showed that the majority of firefighters positively assess the adopted procedures and personal protective equipment, despite accidents that occur during the activities of the State Fire Service. As the responses of the respondents showed, the sports infrastructure in JRG should be improved due to numerous injuries shown by the respondents. The lowest risk to the health of firefighters comes from the operational readiness inspections and training classes. It should be stated, however, that the analysis did not involve a distinction between theoretical and practical classes. All groups, regardless of their positions (commander, rescuer, driver) are susceptible to particular health hazards at a similar level. However, in order to better illustrate the health hazards of firefighters, the research should be extended to other provinces in order to compare health hazards depending on the location (field, demographic, financial conditions). For the z rezultatami niniejszego badania w zakresie zajęć sportowych jako częstej przyczyny kontuzji. We wspomnianej publikacji dominującą przyczyną zdarzeń było nieprawidłowe zachowanie lub nieostrożność. Najczęstszymi urazami w wyniku wypadków były liczne złamania, pęknięcia kości i zwichnięcia. Jednak na bezpieczeństwo podczas zajęć sportowych wpływ ma nie tylko zachowanie ostrożności. Duże znaczenie ma wykonanie odpowiedniej dla danych zajęć rozgrzewki, jak również infrastruktura oraz sprzęt sportowy, który użytkowany jest do ćwiczeń. W ocenie autorów stan techniczny obiektów i sprzętu wykorzystywanego do szeroko rozumianych zajęć sportowych (w tym sport pożarniczy, zajęcia sportowe indywidualne, drużynowe) pozostawia niejednokrotnie wiele do życzenia. Biorąc pod uwagę, że w obecnym badaniu ankietowym tylko ogólnikowo została zawarta kategoria „zajęcia sportowe" (zob. tabela 4), zdaniem autorów wnikliwa analiza zajęć sportowych jako znaczącego czynnika narażenia na zagrożenia zdrowotne powinna być przedmiotem badań w przyszłości.

M. Wejnman i wsp. w pracy z 2013 roku [15] oraz W. Andruszkiewicz i wsp. w publikacji z 2011 roku [16] opisują zawód strażaka jako zakwalifikowany do grupy o bardzo wysokim poziomie ryzyka. Podczas wykonywania obowiązków służbowych strażacy często są narażeni na znaczne obciążenia zawodowe, które niekorzystnie wpływają na ich zdrowie, a niejednokrotnie zagrażają życiu. Ponadto autorzy wymieniają czynniki szkodliwe dla zdrowia strażaków: zanieczyszczenia powietrza, hałas, obciążenie fizyczne, stres zawodowy, zmienny dobowy rytm pracy, praca na wysokościach, działania w SGR. Wymienione zagrożenia w większości pokrywają się z tymi analizowanymi w niniejszej pracy (tabela 3).

Ponadto badaniem zagrożeń zdrowotnych funkcjonariuszy zajęli się S. Kokot Góra i wsp. w publikacji z 2019 roku [17], jak również G. K. LeMasters i wsp. w pracy z 2006 roku [18]. Autorzy przeanalizowali niepokojące trendy $w$ sferze zachorowalności na nowotwory wśród strażaków i zagrożenia ze strony dymu - zarówno z perspektywy działań gaśniczych, jak i ochrony zdrowia. Substancje niebezpieczne, które powstają w wyniku niekontrolowanego procesu spalania, $w$ tym toksyczne oraz rakotwórcze, nie zostały jeszcze do końca rozpoznane.

\section{Wnioski}

Analiza wykazała, że większość strażaków pozytywnie ocenia przyjęte procedury postępowania i środki ochrony osobistej, pomimo wypadków, jakie zdarzają się podczas działań PSP. Jak wykazały odpowiedzi ankietowanych, infrastruktura sportowa w JRG powinna zostać poprawiona ze względu na liczne urazy wykazywane przez respondentów. Najmniejsze ryzyko dla zdrowia strażaków niosą inspekcje gotowości operacyjnej i zajęcia szkoleniowe, przy czym analiza nie weryfikowała szkoleń z podziałem zajęć na teoretyczne i praktyczne. Wszystkie grupy niezależnie od zajmowanych stanowisk (dowódca, ratownik, kierowca) - są podatne na poszczególne zagrożenia zdrowotne na podobnym poziomie. Jednak dla lepszego zobrazowania zagrożeń zdrowotnych strażaków badania należy rozszerzyć na inne województwa w celu porównania zagrożeń zdrowotnych zależnych od lokalizacji (warunki terenowe, demograficzne, finansowe). 
purpose of reducing the risk of health hazards occurring in the State Fire Service, it is necessary for firefighters to properly use personal protective equipment. Close attention should be paid to the fact whether the rescuers are properly secured in terms of skin and respiratory system.

\section{List of abbreviations}

$\begin{array}{ll}\text { OHS } & \text { - occupational health and safety } \\ \text { CO } & \text { - carbon monoxide } \\ \text { RFFU } & \text { - rescue and fire fighting unit } \\ \text { HIV } & \text { - human immunodeficiency virus } \\ \text { CC } & \text { - city commands } \\ \text { DH } & \text { - district headquarters } \\ \text { QFA } & \text { - qualified first aid } \\ \text { PH } & \text { - provincial headquarters } \\ \text { TCPH } & \text { - training center of the provincial headquarters } \\ \text { SFS } & \text { - State Fire Service } \\ \text { CD } & \text { - combat division } \\ \text { SRG } & \text { - Specialist Rescue Group } \\ \text { CP } & \text { - Command Post } \\ \text { VH } & \text { - viral hepatitis }\end{array}$

\section{Literature / Literatura}

[1] Rozporządzenie Ministra Spraw Wewnętrznych i Administracji z dn. 3.07.2017 r. w sprawie szczegółowej organizacji Krajowego Systemu Ratowniczo-Gaśniczego (Dz. U. 2017, poz. 1319).

[2] Sawicki T., Bezpieczeństwo strażaków a ryzyko zawodowe, „W akcji" 2012, 2, 46.

[3] Rozporządzenie Ministra Spraw Wewnętrznych i Administracji z dnia 16 września 2008 roku w sprawie szczegółowych warunków bezpieczeństwa i higieny służby strażaków Państwowej Straży Pożarnej (Dz. U. 2008 Nr 180, poz. 1115).

[4] Rozporządzenie Ministra Spraw Wewnętrznych i Administracji z dnia 27 października 2005 r. w sprawie zakresu, trybu i częstotliwości przeprowadzania okresowych profilaktycznych badań lekarskich oraz okresowej oceny sprawności fizycznej strażaka Państwowej Straży Pożarnej (Dz.U. $2005 \mathrm{Nr}$ 261, poz. 2191).

[5] Ustawa z dnia 24 sierpnia 1991 r. o Państwowej Straży Pożarnej (t.j.: Dz. U. 2019, poz. 1499, 1635, 1726, 2020).

[6] http://www.ciop.pl/, Centralny Instytut Ochrony Pracy Państwowy Instytut Badawczy, Międzynarodowa karta charakterystyki zagrożeń zawodowych [dostęp: 10.12.2019].

[7] http://www.straz.gov.pl/państwowa_straz_pozarna/jednostki_psp [dostęp: 1.10.2019].
Aby zmniejszyć ryzyko wystąpienia zagrożeń zdrowotnych w PSP, konieczne jest prawidłowe stosowanie przez strażaków środków ochrony indywidualnej. Należy też zwiększyć dbałość o właściwe zabezpieczenie ratowników w zakresie ochrony skóry i dróg oddechowych.

\section{Wykaz skrótów}

$\begin{array}{ll}\text { BHP } & \text { - bezpieczeństwo i higiena pracy } \\ \text { CO } & \text { - tlenek węgla } \\ \text { JRG } & \text { - jednostka ratowniczo-gaśnicza } \\ \text { HIV } & - \text { (ang. human immunodeficiency virus) ludzki } \\ & \quad \text { wirus niedoboru odporności } \\ \text { KM } & \text { - komenda miejska } \\ \text { KP } & \text { - komenda powiatowa } \\ \text { KPP } & \text { - kwalifikowana pierwsza pomoc } \\ \text { KW } & \text { - komenda wojewódzka } \\ \text { OSKW } & \text { - ośrodek szkolenia komendy wojewódzkiej } \\ \text { PSP } & \text { - Państwowa Straż Pożarna } \\ \text { PB } & \text { - podział bojowy } \\ \text { SGR } & \text { - specjalistyczna grupa ratownicza } \\ \text { SK } & \text { - stanowisko kierowania } \\ \text { WZW } & \text { - wirusowe zapalenie wątroby }\end{array}$

[8] Plan PRM w woj. lubelskim wersja VIII, Jednostki Ratowniczo-Gaśnicze PSP w woj. lubelskim, 2008, s. 236.

[9] KW PSP Lublin - dane kadrowe dotyczące pracowników systemu codziennego i zmianowego [dostęp: 1.03.2020].

[10] Rozkaz nr 48.2018 Lubelskiego Komendanta Wojewódzkiego Państwowej Straży Pożarnej z dnia 11 czerwca 2018 w sprawie Organizacji Lubelskiej Brygady Odwodowej.

[11] Rozkaz nr 19 Komendanta Głównego PSP z dnia 29 maja 2018 roku w sprawie organizacji centralnego odwodu operacyjnego krajowego systemu ratowniczo-gaśniczego.

[12] Korenkiewicz I., Narażenie zawodowe funkcjonariuszy Państwowej Straży Pożarnej, PIS MSWiA, Białystok 2004, http://www.pis.mswia.gov.pl/is/materialy-szkoleniowe/ higiena-pracy [dostęp: 1.12.2019].

[13] Dane statystyczne KG PSP, https://danepubliczne.gov.pl/ organization/komenda-glowna-panstwowej-strazy-pozarnej [dostęp: 1.06.2019].

[14] Pawlak A., Gotlib J., Gałązkowski R., Analiza występowania i skutków wypadków w środowisku pracy strażaków Państwowej Straży Pożarnej w latach 2008-2013, „Medycyna Pracy" 2016,67(1), 1-9, https://doi.org/10.13075/ mp.5893.00086.

[15] Wejnman M., Przybylski K., Identyfikacja zagrożeń na stanowiskach pracy strażaków zawodowych, „Zeszyty Naukowe Politechniki Poznańskiej" 2013, 59, 69-84. 
[16] Andruszkiewicz W., Kapusta M., Nowak-Senderowska D., Identyfikacja i ocena typowych zagrożeń na stanowisku pracy strażaka-ratownika, Wyd. AGH, Kraków 2011.

[17] Kokot Góra S., Porowski R., Słupik D., Zapobieganie nowotworom cz. I. Warsztat Ratownika, "Przegląd Pożarniczy” 2019, 1.

ŁUKASZ CZYŻEWSKI, M.D., D.SC. - assistant professor at the Department of Nephrology Nursing, Medical University of Warsaw.

ŁUKASZ DUDZIŃSKI, DOCTOR OF HEALTH SCIENCES - State Fire Service officer, serves at Municipal Headquarters of the State Fire Service in Lublin. He is a SFS medical rescue trainer and a rescuer emplyed at Independent Public Complex of Health Care in Łuków.

DOMINIK WYSOCKI, M.ENG. - Chief oficer of a Training Centre at the Provincial Headquarters of the State Fire Service in Lublin.
[18] LeMasters G. K., Ash M. i in., Cancer Risk Among Firefighters: A Review and Meta-analysis of 32 Studies, “Journal of Occupational Environmental Medicine" 2006, 48(11), 1189-1202, https://doi.org/10.1097/01.jom.0000246229.68697.90.
DR HAB. N. MED. ŁUKASZ CZYŻEWSKI - adiunkt w Zakładzie Pielęgniarstwa Nefrologicznego, Warszawski Uniwersytet Medyczny.

DR N. O ZDR. ŁUKASZ DUDZIŃSKI - funkcjonariusz Państwowej Straży Pożarnej, pełni służbę w Komendzie Miejskiej PSP w Lublinie. Jest instruktorem ratownictwa medycznego w PSP oraz ratownikiem medycznym w Samodzielnym Publicznym Zakładzie Opieki Zdrowotnej w Łukowie.

MGR INŻ. DOMINIK WYSOCKI - naczelnik Ośrodka Szkolenia Komendy Wojewódzkiej Państwowej Straży Pożarnej w Lublinie. 